\title{
Respons fisiologis tanaman kentang terhadap jenis zat pengatur tumbuh pada berbagai kondisi cekaman kekeringan di dataran medium
}

Sari Peningkatan suhu global akibat peningkatan konsentrasi $\mathrm{CO}_{2}$ di atmosfer sangat berpotensi terjadi cekaman kekeringan pada tanaman kentang. Fenomena ini dapat mempengaruhi proses fisiologis tanaman. Zat Pengatur Tumbuh (ZPT) asam salisilat dan paclobutrazol mampu memberikan perlindungan bagi tanaman terhadap cekaman kekeringan melalui serangkaian proses fisiologis seperti peningkatan aktivitas fotosintesis. Penelitian ini bertujuan untuk mengetahui interaksi antara ZPT dan cekaman kekeringan serta memperoleh jenis ZPT dan kondisi cekaman kekeringan yang masih mampu menghasilkan karakter fisiologis tanaman kentang terbaik di dataran medium. Percobaan bertempat di Kebun Percobaan Ciparanje, Jatinangor, pada ketinggian $685 \mathrm{~m}$ di atas permukaan laut. Rancangan percobaan yang digunakan adalah rancangan petak terbagi. Petak utama terdiri dari interval penyiraman 1, 4, 8, dan 12 hari, sedangkan anak petak terdiri atas tanpa ZPT, asam salisilat, paclobutrazol, serta kombinasi asam salisilat dan paclobutrazol. Setiap perlakuan diulang sebanyak 3 kali. Hasil penelitian menunjukkan bahwa tidak terdapat pengaruh interaksi antara jenis ZPT dengan cekaman kekeringan terhadap seluruh parameter fisiologis. Penambahan ZPT paclobutrazol mampu menghasilkan respons terbaik terhadap konduktansi stomata serta suhu kanopi. Sementara itu, tanaman kentang pada 9 MST masih mampu memberikan respons fluoresensi klorofil terbaik hingga interval penyiraman 4 hari.

Kata kunci: Kentang · Cekaman kekeringan · Asam salisilat · Paclobutrazol

\section{Physiological responses of potato plant to the types of plant growth regulator under various drought stress condition in medium altitude}

\begin{abstract}
The rising of $\mathrm{CO}_{2}$ concentration increases global temperature. This phenomenon potentially causes drought stress in potato plant and lead to interfere its physiological process. Plant growth regulator (PGR) such as salicylic acid and paclobutrazol are expected to protect the plant due to the drought stress through improving photosynthesis activity. This study aimed to understand the interaction between PGR and drought stress; and find out the types of PGR and drought stress condition which are able to provide the best physiological responses of potato plant in medium altitude. The experiment was conducted in Ciparanje Experimental Field, Jatinangor, at an altitude 685 $\mathrm{m}$ above sea level. Split plot design was used as the experimental design. The main plot was watering interval, consisted of 1, 4, 8, and 12 day; while the subplot was PGR treatment, consisted of non-PGR, salicylic acid, paclobutrazol, and the combination of salicylic acid and paclobutrazol. All of the treatments were replicated for 3 times. The results showed that interactions were not occurred between PGR and drought stress to all physiological parameters. The treatment of paclobutrazol exhibited stomatal conductance and canopy temperature. Meanwhile, the potato plant showed good responses on chlorophyll fluorescence 9 WAP until 4 days watering interval.
\end{abstract}

Keywords: Potato $\cdot$ Drought stress $\cdot$ Salicylic acid $\cdot$ Paclobutrazol

Diterima : 5 Desember 2019, Disetujui : 21 Maret 2020, Dipublikasikan : 31 Maret 2020 doi: https://doi.org/10.24198/kultivasi.v19i1.24972

\footnotetext{
Yuniati, N. · J. S. Hamdani · M. A. Soleh

Fakultas Pertanian Unpad

Korespondensi: nitayun95@gmail.com.
} 


\section{Pendahuluan}

Kentang (Solanum tuberosum L.) merupakan salah satu tanaman hortikultura yang bernilai ekonomis tinggi dan menempati urutan ke-4 sebagai bahan pangan yang paling banyak dikonsumsi di dunia (FAO, 2011). Indonesia merupakan salah satu negara yang telah mengembangkan komoditas kentang. Salah kentang yang sedang dikembangkan di Indonesia adalah kentang kultivar Medians.

Tanaman kentang di Indonesia secara umum dibudidayakan di dataran tinggi (Handayani et al., 2011), namun terbatasnya lahan dan kurangnya upaya konservasi lahan untuk mencegah longsor menjadi permasalahan budidaya kentang di dataran tinggi (Duaja, 2012). Perluasan areal tanam kentang di dataran medium merupakan solusi untuk mengatasi permasalahan tersebut. Hal ini juga didukung oleh sifat tanaman kentang kultivar Medians yang mampu beradaptasi dengan baik saat ditanam di dataran medium.

Tanaman kentang cukup sensitif terhadap perubahan iklim (Aliche et al., 2018). IPCC (2007) memprediksi adanya kenaikan suhu global lebih dari $5^{\circ} \mathrm{C}$ hingga tahun 2100. Peningkatan suhu ini disebabkan oleh semakin meningkatnya konsentrasi $\mathrm{CO}_{2}$ di atmosfer (NOAA, 2018). Fenomena ini berpotensi mengakibatkan kekeringan dalam jangka waktu panjang (Swann et al., 2016). Cekaman kekeringan mempengaruhi serangkaian proses fisiologis tanaman kentang, seperti terganggunya aktivitas fotosintesis (Yordanov et al., 2003). Solusi untuk mengatasi masalah cekaman kekeringan pada tanaman kentang adalah dengan aplikasi Zat Pengatur Tumbuh (ZPT) asam salisilat dan paclobutrazol.

Asam salisilat merupakan salah satu jenis ZPT yang dapat memberikan perlindungan terhadap cekaman kekeringan dengan mempertahankan potensial osmotik dan status nutrisi tanaman, serta meningkatkan enzim antioksidan dan metabolit sekunder (Khan et al., 2015). Paclobutrazol juga merupakan salah satu ZPT yang dapat meningkatkan toleransi tanaman terhadap kekeringan, karena berperan dalam meningkatkan aktivitas fotosintesis, enzim, dan kandungan senyawa osmolit; serta mempertahankan indeks stabilitas membran. (Soumya et al., 2017). Aplikasi cekaman kekeringan pada tanaman dapat diberikan berupa berbagai interval penyiraman. Semakin lama tingkat interval penyiraman yang diberikan, maka tanaman semakin tercekam dan jenis ZPT tertentu akan bekerja efektif pada interval penyiraman tertentu, sehingga pemilihan jenis ZPT untuk tanaman kentang harus tepat.

Berdasarkan latar belakang yang telah dipaparkan, maka perlu dilakukan penelitian lebih lanjut mengenai respons fisiologis tanaman kentang terhadap jenis ZPT pada berbagai kondisi cekaman kekeringan di dataran medium. Penelitian ini bertujuan untuk mengetahui interaksi jenis ZPT dan cekaman kekeringan serta memperoleh jenis ZPT yang tepat pada kondisi cekaman kekeringan tertentu yang mampu memberikan karakter fisiologis tanaman kentang terbaik di dataran medium.

\section{Bahan dan Metode}

Percobaan dilaksanakan pada bulan Februari Mei 2019 dan bertempat di Kebun Ciparanje, Jatinangor $(685 \mathrm{~m} \mathrm{dpl})$. Tipe iklim di tempat percobaan menurut klasifikasi Oldeman yaitu tipe iklim C3. Tanah yang digunakan adalah tanah ordo Inceptisol.

Alat-alat yang digunakan adalah pipet tetes, timbangan analitik, gelas ukur, sprayer, thermohygrometer, chlorophyll meter (KWF China Co., Ltd), leaf porometer (Decagon Devices), Handy PEA fluorometer (Hansatech Instruments), thermal imaging camera (Flir Systems), dan oven.

Bahan-bahan yang digunakan yaitu benih kentang $\mathrm{G}_{1}$ kultivar Medians, tanah Inceptisol, pupuk kandang sapi, pupuk Urea $(45 \% \mathrm{~N})$, pupuk TSP $\left(46 \% \mathrm{P}_{2} \mathrm{O}_{5}\right)$, pupuk $\mathrm{KCl}\left(60 \% \mathrm{~K}_{2} \mathrm{O}\right)$, asam salisilat murni, paclobutrazol Goldstar 250 SC (bahan aktif Paclobutrazol $250 \mathrm{~g} \mathrm{~L} \mathrm{~L}^{-1}$ ), fungisida Dithane M-45 (bahan aktif Mankozeb 80\%), insektisida Curacron 500 EC (bahan aktif Profenofos $500 \mathrm{~g} \mathrm{~L}^{-1}$ ), polybag hitam diameter 50 $\mathrm{cm} \times 50 \mathrm{~cm}$, label, plastik UV, mulsa plastik hitam perak, dan jaring net.

Percobaan dilakukan menggunakan rancangan petak terbagi (split plot design). Interval penyiraman (K) merupakan petak utama yang terdiri atas interval 1 hari (tanpa cekaman), 4 hari, 8 hari, dan 12 hari. Jenis ZPT (Z) merupakan anak petak yang terdiri atas tanpa aplikasi ZPT, asam salisilat, paclobutrazol, dan kombinasi asam salisilat + paclobutrazol. Setiap perlakuan diulang sebanyak 3 kali, sehingga terdapat 48 satuan percobaan. Setiap 
satuan percobaan terdiri atas 8 tanaman yang ditanam dalam polybag dan ditempatkan di atas bedengan yang dilapisi oleh mulsa plastik hitam perak dan di bawah naungan plastik UV.

Perlakuan ZPT diberikan saat 4 MST pada konsentrasi 100 ppm. Pemberian paclobutrazol pada perlakuan kombinasi asam salisilat dan paclobutrazol dilakukan 9 hari setelah pemberian asam salisilat. Perlakuan cekaman kekeringan yang diberikan adalah berupa interval penyiraman selama fase pengisian ubi. Pengamatan terdiri dari fluoresensi klorofil, konduktansi stomata, suhu kanopi, dan kandungan sukrosa daun. Analisis kandungan sukrosa daun dilaksanakan di Balai Penelitian Sayuran, Lembang, menggunakan metode Luff Schoorl.

Data dianalisis dengan uji $\mathrm{F}$ pada taraf nyata 5\% menggunakan software SPSS 21 . Jika terdapat signifikansi maka dilanjutkan dengan Uji Jarak Berganda Duncan pada taraf nyata 5\%.

\section{Hasil dan Pembahasan}

Fluoresensi Klorofil. Hasil analisis statistik menunjukkan bahwa tidak terdapat interaksi jenis ZPT dengan berbagai kondisi cekaman kekeringan terhadap fluoresensi klorofil $\left(\mathrm{F}_{\mathrm{v}} / \mathrm{F}_{\mathrm{m}}\right)$ di setiap waktu pengamatan. Pengaruh mandiri terhadap $\mathrm{F}_{\mathrm{v}} / \mathrm{F}_{\mathrm{m}}$ disajikan pada Tabel 1.

Berdasarkan Tabel 1, perlakuan interval penyiraman berpengaruh nyata terhadap $\mathrm{F}_{\mathrm{v}} / \mathrm{F}_{\mathrm{m}}$ saat 7 MST dan 9 MST, namun tidak berpengaruh nyata ketika 11 MST. Saat 7 MST, perlakuan interval penyiraman 4 hari menunjukkan nilai $\mathrm{F}_{\mathrm{v}} / \mathrm{F}_{\mathrm{m}}$ lebih tinggi dari interval penyiraman 12 hari, tetapi tidak berbeda nyata dengan perlakuan interval penyiraman 1 hari dan 8 hari. Saat 9 MST, perlakuan interval penyiraman 1 hari menunjukkan $F_{v} / F_{m}$ lebih tinggi dibandingkan interval penyiraman lainnya, tetapi tidak berbeda nyata dengan interval penyiraman 4 hari.

Zlatev (2013) menyatakan bahwa cekaman kekeringan menurunkan $\mathrm{F}_{\mathrm{v}} / \mathrm{F}_{\mathrm{m}}$ tanaman buncis. Penurunan $\mathrm{F}_{\mathrm{v}} / \mathrm{F}_{\mathrm{m}}$ mengindikasikan jumlah energi cahaya yang ditransformasikan di dalam pusat reaksi fotosistem II menurun, sehingga terjadi perubahan aktivitas fotokimia yang menyebabkan aktivitas fotosintesis menjadi terbatas ketika kekeringan (Puteh et al., 2013). Zlatev (2014) mengungkapkan bahwa penurunan $\mathrm{F}_{\mathrm{v}} / \mathrm{F}_{\mathrm{m}}$ saat kekeringan diakibatkan oleh fotoinhibisi dan fotoinaktivasi di pusat reaksi fotosistem II karena rusaknya protein D1, sehingga aktivitas fotosintesis menjadi terganggu (Hui-Jie et al., 2011).

Perlakuan zat pengatur tumbuh (ZPT) tidak berpengaruh nyata terhadap $\mathrm{F}_{\mathrm{v}} / \mathrm{F}_{\mathrm{m}}$ di setiap waktu pengamatan. Arfan et al. (2007) menyatakan bahwa asam salisilat tidak mempengaruhi $\mathrm{F}_{\mathrm{v}} / \mathrm{F}_{\mathrm{m}}$ tanaman gandum. Nzokou dan Nikiema (2008) juga mengungkapkan bahwa aplikasi ZPT prohexadione-Ca, paclobutrazol, dan flurmpimidol tidak memberikan perbedaan yang nyata terhadap $\mathrm{F}_{\mathrm{v}} / \mathrm{F}_{\mathrm{m}}$. Hal ini mengindikasikan bahwa penambahan ZPT tidak mempengaruhi efisiensi maksimum cahaya yang diserap fotosistem II dalam percobaan ini. Walaupun demikian, seiring bertambahnya waktu tampak bahwa aplikasi seluruh ZPT menampilkan tren pertambahan nilai $\mathrm{F}_{\mathrm{v}} / \mathrm{F}_{\mathrm{m}}$, sedangkan perlakuan tanpa ZPT justru mengalami penurunan.

Tabel 1. Pengaruh mandiri jenis zat pengatur tumbuh dan berbagai kondisi cekaman kekeringan terhadap fluoresensi klorofil 7 MST, 9 MST, dan 11 MST

\begin{tabular}{cccc}
\hline \multicolumn{1}{c}{ Perlakuan } & \multicolumn{3}{c}{ Fluoresensi Klorofil $\left(\mathbf{F}_{\mathbf{v}} / \mathbf{F}_{\mathbf{m}}\right)$} \\
\cline { 2 - 3 } & $\mathbf{7 ~ M S T}$ & $\mathbf{9 ~ M S T}$ & $\mathbf{1 1} \mathbf{M S T}$ \\
\hline Interval Penyiraman (K) & $0,69 \mathrm{ab}$ & $0,73 \mathrm{~b}$ & $0,75 \mathrm{a}$ \\
1 hari & $0,71 \mathrm{~b}$ & $0,70 \mathrm{ab}$ & $0,71 \mathrm{a}$ \\
4 hari & $0,69 \mathrm{ab}$ & $0,68 \mathrm{a}$ & $0,71 \mathrm{a}$ \\
8 hari & $0,66 \mathrm{a}$ & $0,67 \mathrm{a}$ & $0,69 \mathrm{a}$ \\
12 hari & & & $0,66 \mathrm{a}$ \\
Zat Pengatur Tumbuh (Z) & $0,70 \mathrm{a}$ & $0,69 \mathrm{a}$ & $0,71 \mathrm{a}$ \\
tanpa ZPT & $0,68 \mathrm{a}$ & $0,69 \mathrm{a}$ & $0,72 \mathrm{a}$ \\
asam salisilat & $0,67 \mathrm{a}$ & $0,69 \mathrm{a}$ & $0,73 \mathrm{a}$ \\
\hline paclobutrazol & $0,69 \mathrm{a}$ & $0,72 \mathrm{a}$ &
\end{tabular}

Keterangan : Angka yang diikuti dengan notasi huruf yang sama pada kolom yang sama tidak berbeda nyata berdasarkan Uji Jarak Berganda Duncan pada taraf nyata 5\%. 
Konduktansi Stomata. Hasil analisis statistik menunjukkan bahwa tidak terdapat interaksi jenis zat pengatur tumbuh (ZPT) dengan berbagai kondisi cekaman kekeringan terhadap konduktansi stomata di setiap waktu pengamatan. Pengaruh mandiri terhadap konduktansi stomata disajikan pada Tabel 2.

Berdasarkan Tabel 2, perlakuan interval penyiraman berpengaruh nyata terhadap konduktansi stomata. Perlakuan interval penyiraman 1 hari menunjukkan konduktansi stomata paling tinggi. Selain itu, semakin lama waktu interval penyiraman, maka semakin menurunkan konduktansi stomata. Romero et al. (2017) melaporkan bahwa cekaman kekeringan menurunkan konduktansi stomata tanaman kentang. Penutupan stomata merupakan mekanisme tanaman untuk menurunkan transpirasi saat kekeringan (Taiz dan Zeiger, 2002).

Perlakuan ZPT berpengaruh nyata terhadap konduktansi stomata saat 9 MST dan 11 MST. Saat 9 MST, perlakuan kombinasi asam salisilat + paclobutrazol menunjukkan konduktansi stomata lebih tinggi dibandingkan ZPT lainnya, namun tidak berbeda nyata dengan paclobutrazol. Ketika 11 MST, perlakuan tersebut juga menunjukkan konduktansi stomata yang tidak berbeda nyata dengan perlakuan paclobutrazol dan asam salisilat.

Menurut Nazar et al. (2015), asam salisilat dapat meningkatkan konduktansi stomata baik dalam keadaan cekaman kekeringan maupun optimal, sehingga mampu meningkatkan konsentrasi $\mathrm{CO}_{2}$ interseluler dan enzim Rubisco. Asam salisilat berperan dalam menstimulasi ketersediaan unsur N (nitrogen) dan S (sulfur), sehingga meningkatkan aktivitas nitrat reduktase dan ATP-sulfurilase yang berguna untuk proses fotosintesis (Nazar et al., 2011).

Menurut Zhao et al. (2015), peningkatan konduktansi stomata berkorelasi dengan tingginya kadar air relatif daun dan serapan air oleh akar. Aplikasi asam salisilat meningkatkan panjang, diameter, dan berat kering akar pada kondisi optimal maupun kekeringan, sehingga kemampuan tanaman menyerap air di dalam tanah menjadi lebih baik (Askari dan Ehsanzadeh, 2015). Hasil penelitian Kamran et al. (2018) juga menunjukkan peningkatan berat kering dan panjang akar pada tanaman jagung yang diberi paclobutrazol. Xia et al. (2018) melaporkan bahwa aplikasi paclobutrazol secara signifikan meningkatkan konduktansi stomata tanaman Paeonia lactiflora, karena paclobutrazol memicu sintesis hormon sitokinin yang berperan mendorong pembukaan stomata (Pal et al., 2016).

Suhu Kanopi. Hasil analisis statistik menunjukkan bahwa tidak terdapat interaksi jenis ZPT dan berbagai kondisi cekaman kekeringan terhadap suhu kanopi di setiap waktu pengamatan. Pengaruh mandiri terhadap suhu kanopi disajikan pada Tabel 3.

Berdasarkan Tabel 3, perlakuan interval penyiraman tidak berpengaruh nyata terhadap suhu kanopi saat 7 MST dan 9 MST, namun berpengaruh nyata saat 11 MST. Saat 11 MST, perlakuan interval penyiraman 12 hari menunjukkan suhu kanopi yang lebih tinggi dari interval penyiraman 1 hari dan 4 hari, namun tidak berbeda nyata dengan interval penyiraman 8 hari.

Hasil penelitian ini menunjukkan bahwa semakin lama waktu interval penyiraman, maka semakin meningkatkan suhu kanopi. Menurut

Tabel 2. Pengaruh mandiri jenis zat pengatur tumbuh dan berbagai kondisi cekaman kekeringan terhadap konduktansi stomata 7 MST, 9 MST, dan 11 MST.

\begin{tabular}{|c|c|c|c|}
\hline \multirow{2}{*}{ Perlakuan } & \multicolumn{3}{|c|}{ Konduktansi Stomata $\left(\mathrm{mmol} \mathrm{H}_{2} \mathrm{O} \mathrm{m}^{-2} \mathrm{~s}^{-1}\right)$} \\
\hline & $7 \mathrm{MST}$ & 9 MST & 11 MST \\
\hline \multicolumn{4}{|l|}{ Interval Penyiraman (K) } \\
\hline 1 hari & $254,43 \mathrm{c}$ & $154,87 \mathrm{~d}$ & $93,04 \mathrm{c}$ \\
\hline 4 hari & $185,53 \mathrm{~b}$ & $87,48 \quad \mathrm{c}$ & $52,08 \mathrm{~b}$ \\
\hline 8 hari & $151,34 \mathrm{~b}$ & $54,80 \mathrm{~b}$ & $36,47 \mathrm{ab}$ \\
\hline 12 hari & 59,84 a & 24,62 a & $19,72 \mathrm{a}$ \\
\hline \multicolumn{4}{|l|}{ Zat Pengatur Tumbuh (Z) } \\
\hline tanpa ZPT & $148,51 \mathrm{a}$ & 70,68 a & 36,62 a \\
\hline asam salisilat & $163,52 \mathrm{a}$ & 59,90 a & $45,56 \mathrm{ab}$ \\
\hline paclobutrazol & $166,66 \mathrm{a}$ & $84,35 \mathrm{ab}$ & $57,37 \mathrm{~b}$ \\
\hline asam salisilat + paclobutrazol & $172,45 \mathrm{a}$ & $106,83 \mathrm{~b}$ & $61,77 \mathrm{~b}$ \\
\hline
\end{tabular}

Keterangan : Angka yang diikuti dengan notasi huruf yang sama pada kolom yang sama tidak berbeda nyata berdasarkan Uji Jarak Berganda Duncan pada taraf nyata 5\%. 
Sinha et al. (2019), peningkatan suhu kanopi dikarenakan adanya pengaruh dari konduktansi stomata. Penurunan laju transpirasi akibat konduktansi stomata yang rendah menyebabkan suhu kanopi meningkat. Penutupan stomata mengakibatkan perubahan keseimbangan energi di dalam tanaman, yakni energi panas yang dibuang melalui transpirasi menjadi lebih sedikit, sehingga menyebabkan suhu kanopi meningkat (Gimenez et al., 2005). Berdasarkan Tabel 2, konduktansi stomata menurun seiring meningkatnya waktu interval penyiraman dan sebaliknya, suhu kanopi semakin meningkat.

Perlakuan ZPT tidak memberikan perbedaan nyata terhadap suhu kanopi saat 7 MST dan 9 MST, namun berbeda nyata saat 11 MST. Perlakuan kombinasi asam salisilat + paclobutrazol menunjukkan suhu kanopi lebih rendah dari tanpa ZPT, namun tidak berbeda nyata dengan perlakuan paclobutrazol dan asam salisilat. Bakundi dan Yahaya (2017) membuktikan bahwa terjadi penurunan suhu kanopi pada tanaman cabai yang diaplikasikan asam salisilat, sehingga terjadi efek pendinginan yang tinggi pada daun dan suhu kanopi menjadi menurun. Rendahnya suhu kanopi berkorelasi dengan perakaran tanaman yang lebih dalam (Wasaya et al., 2018). Ketika sistem perakaran lebih dalam, akar mampu mensuplai air ke tanaman lebih baik, kemudian memicu pembukaan stomata, dan suhu kanopi menurun.

Seiring meningkatnya umur tanaman, tampak semakin meningkatkan suhu kanopi pada perlakuan cekaman kekeringan dan ZPT. Peningkatan suhu kanopi di setiap pengamatan diduga akibat pengaruh suhu udara yang tinggi saat pengamatan. Rebetzke et al. (2013) memaparkan bahwa suhu udara yang tinggi mempengaruhi suhu kanopi. Suhu udara yang tinggi akan meningkatkan suhu kanopi, dan sebaliknya, dengan menurunnya suhu udara maka akan diiringi oleh penurunan suhu kanopi.

Kandungan Sukrosa Daun. Pengaruh mandiri dari perlakuan cekaman kekeringan dan jenis ZPT terhadap kandungan sukrosa daun tanaman kentang disajikan pada Tabel 4 .

Tabel 3. Pengaruh mandiri jenis zat pengatur tumbuh dan berbagai kondisi cekaman kekeringan terhadap suhu kanopi 7 MST, 9 MST, dan 11 MST.

\begin{tabular}{|c|c|c|c|}
\hline \multirow{2}{*}{ Perlakuan } & \multicolumn{3}{|c|}{ Suhu Kanopi (oC) } \\
\hline & $7 \mathrm{MST}$ & 9 MST & $11 \mathrm{MST}$ \\
\hline \multicolumn{4}{|l|}{ Interval Penyiraman (K) } \\
\hline 1 hari & $26,13 \mathrm{a}$ & 29,29 a & $29,25 \mathrm{a}$ \\
\hline 4 hari & $26,81 \mathrm{a}$ & 29,51 a & $31,43 \mathrm{~b}$ \\
\hline 8 hari & $26,76 \mathrm{a}$ & $30,22 \mathrm{a}$ & $31,92 \mathrm{bc}$ \\
\hline 12 hari & $28,84 \mathrm{a}$ & $30,23 \mathrm{a}$ & $32,40 \mathrm{c}$ \\
\hline \multicolumn{4}{|l|}{ Zat Pengatur Tumbuh (Z) } \\
\hline tanpa ZPT & 27,48 a & 29,99 a & $31,89 \mathrm{~b}$ \\
\hline asam salisilat & $27,19 \mathrm{a}$ & 30,03 a & $31,45 \mathrm{ab}$ \\
\hline paclobutrazol & 27,11 a & 29,43 a & 30,99 a \\
\hline asam salisilat + paclobutrazol & $26,75 \mathrm{a}$ & $29,80 \mathrm{a}$ & 30,67 a \\
\hline \multicolumn{4}{|c|}{$\begin{array}{c}\text { Keterangan : Angka yang diikuti dengan notasi huruf yang sama pada kolom yang sama tidak berbeda nyata } \\
\text { berdasarkan Uji Jarak Berganda Duncan pada taraf nyata } 5 \% .\end{array}$} \\
\hline \multicolumn{4}{|c|}{$\begin{array}{l}\text { Tabel 4. Pengaruh mandiri jenis zat pengatur tumbuh dan berbagai kondisi cekaman kekeringan terhadap } \\
\text { kandungan sukrosa daun }\end{array}$} \\
\hline $\begin{array}{r}\text { Perlakuan } \\
\end{array}$ & \multicolumn{3}{|c|}{ Kandungan Sukrosa Daun $(\%)^{*}$} \\
\hline \multicolumn{4}{|l|}{ Interval Penyiraman (K) } \\
\hline 1 hari & \multicolumn{3}{|c|}{0,09} \\
\hline 4 hari & \multicolumn{3}{|c|}{0,00} \\
\hline 8 hari & \multicolumn{3}{|c|}{0,00} \\
\hline 12 hari & \multicolumn{3}{|c|}{0,28} \\
\hline \multicolumn{4}{|l|}{ Zat Pengatur Tumbuh (Z) } \\
\hline tanpa ZPT & \multicolumn{3}{|c|}{0,14} \\
\hline asam salisilat & \multicolumn{3}{|c|}{0,09} \\
\hline paclobutrazol & \multicolumn{3}{|c|}{0,07} \\
\hline asam salisilat + paclobutrazol & \multicolumn{3}{|c|}{0,07} \\
\hline
\end{tabular}

Keterangan: * tidak dianalisis statistik 
Berdasarkan Tabel 4, perlakuan interval penyiraman 12 hari menampilkan kandungan sukrosa daun tertinggi dibandingkan perlakuan cekaman kekeringan lainnya, sedangkan kandungan sukrosa daun tidak terdeteksi atau diduga kandungannya sangat kecil pada perlakuan interval penyiraman 4 hari dan 8 hari.

$\mathrm{Fu}$ et al. (2010) memaparkan bahwa cekaman kekeringan meningkatkan kandungan sukrosa daun Festuca arundinacea akibat peningkatan aktivitas enzim sukrosa fosfat sintase. Guo et al. (2018) menambahkan bahwa sukrosa merupakan senyawa osmolit kompatibel yang banyak diproduksi tanaman sebagai respons toleransi terhadap cekaman kekeringan. Tingginya kandungan sukrosa daun saat cekaman kekeringan menandakan bahwa terjadi penurunan translokasi asimilat dari daun ke organ lainnya (Anjorin et al., 2016). Oleh karena itu, diduga pada perlakuan interval penyiraman 12 hari, proses translokasi asimilat dari daun menuju ke ubi mulai mengalami gangguan.

Perlakuan interval penyiraman 1 hari menunjukkan nilai kandungan sukrosa daun yang lebih besar dari perlakuan interval penyiraman 4 hari dan 8 hari. Rosa et al. (2009) mengungkapkan bahwa $80 \% \quad \mathrm{CO}_{2} \quad$ yang diasimilasikan selama fotosintesis akan disalurkan untuk sintesis sukrosa. Kandungan sukrosa dari hasil fotosintesis sebagian besar ditransportasikan ke vakuola selama periode terang untuk disimpan, dan pada periode gelap, sukrosa dilepaskan ke floem untuk selanjutnya ditranslokasikan ke organ sink (Endler et al., 2006). Sukrosa yang dihasilkan di daun pada perlakuan interval penyiraman 1 hari diduga memiliki kandungan yang cukup besar karena ketersediaan air pada perlakuan interval penyiraman 1 hari sangat mencukupi bagi pertumbuhan tanaman kentang, sehingga sukrosa yang dihasilkan dan disimpan di dalam vakuola daun pun menjadi lebih besar daripada perlakuan interval penyiraman 4 hari dan 8 hari.

Kandungan sukrosa daun tertinggi ditemukan pada perlakuan tanpa zat pengatur tumbuh. Hal ini diduga karena tanpa penambahan paclobutrazol, sukrosa yang ditranslokasikan dari daun ke ubi kentang lebih sedikit dibandingkan dengan penambahan ZPT. Paclobutrazol berperan dalam mempertahankan potensial air daun saat kekeringan, namun pada pengamatan sukrosa ini fase tanaman telah memasuki fase pengisian ubi. Paclobutrazol dapat mengalihkan distribusi asimilat dari bagian tajuk menuju ke organ sink utama, yaitu ubi (Mabvongwe et al., 2016). Oleh karena itu, perlakuan paclobutrazol dan kombinasi asam salisilat + paclobutrazol menghasilkan kandungan sukrosa daun yang lebih rendah daripada perlakuan tanpa ZPT dan asam salisilat.

\section{Kesimpulan}

Kesimpulan yang dapat diambil dari hasil penelitian ini adalah sebagai berikut :

1. Tidak terdapat pengaruh interaksi antara jenis zat pengatur tumbuh dan berbagai kondisi cekaman kekeringan terhadap fluoresensi klorofil, konduktansi stomata, suhu kanopi, dan kandungan sukrosa daun tanaman kentang.

2. Perlakuan interval penyiraman hingga 4 hari masih mampu menghasilkan respons fluoresensi klorofil yang baik saat 9 MST.

3. Perlakuan zat pengatur tumbuh paclobutrazol lebih efisien dalam memberikan respons konduktansi stomata dan suhu kanopi terbaik.

\section{Ucapan Terima Kasih}

Penulis mengucapkan terimakasih kepada Laboratorium Pemuliaan Tanaman dan Teknologi Benih Fakultas Pertanian Unpad yang telah memfasilitasi alat dan instrumen pada penelitian ini

\section{Daftar Pustaka}

Aliche, E. B., M. Oortwijn, T. P. J. M. Theeuwen, C. W. B. Bachem, R. G. F. Visser, and C. G. V. D. Linden. 2018. Drought response in gield grown potatoes and interactions between canopy growth and yield. Agricultural Water Management 206 : 20-30.

Anjorin, F. B., S. A. Adejumo, L. Agboola, and Y. D. Samuel. 2016. Proline, soluble sugar, leaf starch and relative water contents of four maize varieties in response to different watering regimes. Cercetari Agronomice in Moldova XLIX(3) : 51-62.

Arfan, M., H. R. Athar, and M. Ashraf. 2007. Does exogenous application of salicylic acid through the rooting medium modulate 
growth and photosynthetic capacity in two differently adapted spring wheat cultivars under salt stress?. Journal of Plant Physiology 164 : 685-694.

Bakundi, Y. M. and S. U. Yahaya. 2017. Mitigation of moisture stress in sweet pepper (Capsicum annuum L.) by foliar application of salicylic acid in Sudan Savanna Agro-Ecology, Nigeria. Journal of Dryland Agriculture 3(1) : 10-18.

Duaja, M. D. 2012. Analisis tumbuh umbi kentang (Solanum tuberosum L.) di dataran rendah. Jurnal Bioplantae (1)2 : 88-97.

Endler, A., S. Meyer, S. Schelbert, T. Schneider, W. Weschke, S. W. Peters, F. Keller, S. Baginsky, E. Martinoia, and U. G. Schmidt. 2006. Identification of a vacuolar sucrose transporter in barley and arabidopsis mesophyll cells by a tonoplast proteomic approach. Plant Physiology 141 : 196-207.

FAO. 2011. Food and Agricultural Organization of the United Nations Database. Rome.

Fu, J., B. Huang, and J. Fry. 2010. Osmotic potential, sucrose level, and activity of sucrose metabolic enzymes in tall fescue in response to deficit irrigation. J. Amer. Soc. Hort. Sci. 135(6) : 506-510.

Gimenez, C., M. Gallardo, and R. B. Thompson. 2005. Encyclopedia of Soil in The Environment. Elsevier Ltd. USA.

Guo, R., L. X. Shi, Y. Jiao, M. X. Li, X. L. Zhong, F. X. Gu, Q. Liu, X. Xia, and H. R. Li. 2018. Metabolic responses to drought-tolerant and drought-sensitive wheat genotype seedlings. AoB Plants 10(2) : 1-13.

Handayani, T., E. Sofiari, dan Kusmana. 2011. Karakterisasi morfologi klon kentang di dataran medium. Buletin Plasma Nutfah 17(2) : 116-121.

Hua, S., Y. Zhang, H. Yu, B. Lin, H. Ding, D. Zhang, Y. Ren, and Z. Fang. 2014. Paclobutrazol application effects on plant height, seed yield and carbohydrate metabolism in canola. International Journal of Agriculture \& Biology 16(3) : 471-479.

Hui-Jie, Z., Z. Xue-Juan, M. Pei-Fang, W. YueXia, H. Wei-Wei, L. Li-Hong, and Z. Yi-Dan. 2011. Effects of salicilyc acid on protein kinase activity and chloroplast D1 protein degradation in wheat leaves subjected to heat and high light stress. Acta Ecologica Sinica 31 : 259-263.

IPCC (Intergovermental Panel on Climate Change). 2007. Climate change 2007:
Synthesis Report. https://www.ipcc.ch (Diakses pada tanggal 25 Januari 2020).

Kamran, M., S. Wennan, I. Ahmad, M. Xiangping, C. Wenwen, Z. Xudong, M. Siwei, A. Khan, H. Qinfang, and L. Tiening. 2018. Application of paclobutrazol affect maize grain yield by regulating root morphological and physiological characteristics under a semi-arid region. Scientific Reports 8(4818) : 1-15.

Khan, M. I. R., M. Fatma, T. S. Per, N. A. Anjum and N. A. Khan. 2015. Salicylic acidinduced abiotic stress tolerance and underlying mechanism in plants. Frontiers in Plant Science 6(462) : 1-11.

Mabvongwe, O., B. T. Manenji, M. Gwazane, and M. Chandiposha. 2016. The effect of paclobutrazol application time and variety on growth, yield, and quality of potato (Solanum tuberosum L.). Advances in Agriculture : 1-5.

Nazar, R., N. Iqbal, S. Syeed, and N. A. Khan. 2011. Salicylic acid alleviates decreases in photosynthesis under salt stress by enhancing nitrogen and sulfur assimilation and antioxidant metabolism differentially in two mungbean cultivars. J. Plant Physiol. $168: 807-815$.

Nazar, R., S. Umar, N. A. Khan, and O. Sareer. 2015. Salicylic acid supplementation improves photosynthesis and growth in mustard through changes in proline accumulation and ethylene formation under drought stress. South African Journal of Botany 98 : 85-94.

NOAA (National Oceanic and Atmospheric Administration). 2018. Trends in Atmospheric Carbon Dioxide. https://www.esrl. noaa.gov (Diakses tanggal 12 Januari 2018).

Nzokou, P., and P. Nikiema. 2008. The influence of three plant growth regulators on susceptibility to cold injury following warm winter spells in fraser fir [Abies fraseri (Pursh) Poir] and colorado blue spruce (Picea pungens). HortScience 43(3) : 742-746.

Pal, S., J. Zhao, A. Khan, N. S. Yadav, A. Batushansky, S. Barak. B. Rewald, A. Fait, N. Lazarovitch, and S. Rachmilevitch. 2016. Paclobutrazol induces tolerance in tomato to deficit irrigation through diversified effects on plant morphology, physiology, and metabolism. Nature (6)39321 : 1-13.

Puteh, A. B., A. A. Saragih, M. R. Ismail, and M. M. A. Mondal. 2013. Chlorophyll 
fluorescence parameters of cultivated (Oryza sativa L. ssp indica) and weedy rice (Oryza sativa L. var. nivara) genotypes under water stress. Australian Journal of Crop Science 7(9) : 1277-1283.

Rebetzke, G. J., A. R. Rattey, G. D. Farquhar, R. A. Richards, and A. G. Condon. 2013. Genomic regions for canopy temperature and their genetic association with stomatal conductance and grain yield in wheat. Functional Plant Biology 40(1) : 14-33.

Romero, A. P., A. Alarcon, R. I. Valbuena, and C. H. Galeano. 2017. Physiological assessment of water stress in potato using spectral information. Frontiers in Plant Science 8(1608) : 1-13

Rosa, M., C. Prado, G. Podazza, R. Interdonato, J. A. Gonzales, M. Hilal, and F. E. Prado. 2009. Soluble sugars - metabolism, sensing and abiotic stress. Plant Signaling \& Behaviour 4(5) : 388-393.

Sinha, R., V. Irulappan, B. Mohan-Raju, A. Suganthi, and M. Senthil-Kumar. 2019. Impact of drought stress on simultaneously occurring pathogen infection in field-grown chickpea. Scientific Reports 9(5577) : 1-15.

Soumya, P. R., P. Kumar, and M. Pal. 2017. Paclobutrazol : a novel plant growth regulator and multi-stress ameliorant. Ind J
Plant Physiol 22(3) : 267-278.

Swann, A. L. S., F. M. Hoffman, C. D. Koven, and J. T. Raderson. 2016. Plant responses to increasing $\mathrm{CO}_{2}$ reduce estimates of climate impacts on drought severity. PNAS 113(36) : 10019-10024.

Taiz, L. and E. Zeiger. 2002. Plant Physiology 3 $3^{\text {rd }}$ Edition. Sinauer Associates. Sunderland, USA.

Wasaya, A., X. Zhang, Q. Fang, and Z. Yan. 2018. Root phenotyping for drought tolerance : a review. Journal Agronomy 8(241) : 1-19.

Xia, X., Y. Tang, M. Wei, and D. Zhao. 2018. Effect of paclobutrazol application on plant photosynthetic performance and leaf greenness of herbaceous peony. Horticulturae 4(5) : 1-12.

Yordanov, I., V. Velikova, and T. Tsonev. 2003. Plant responses to drought and stress tolerance. Bulg. J. Plant Physiol Issue 2003: 187-206.

Zlatev, Z. 2013. Drought-induced changes and recovery of photosynthesis in two bean cultivars (Phaseolus vulgaris L.). Emir. J. Food Agric. 25(12) : 1014-1023.

2014. Drought-induced changes in chlorophyll fluorescence of young wheat plants. Biotechnology \& Biotechnological Equipment 23(1) : 438-4 